\title{
IMAGINING HOW A COMPANY THINKS: WhAT IS CORPORATE CULTURE?
}

\author{
ALICE BELCHER ${ }^{*}$
}

[Corporate responsibility for crimes that require thought, or lack of thought, has been the subject of much debate both in the UK and worldwide. This article investigates the current position in the UK, where a Bill is currently (October 2006) before Parliament, and briefly in Australia, where the law has been reformed at Commonwealth level, but not yet implemented in individual States. In line with developments in Australian and the UK law a realist rather than nominalist position is taken that explicitly recognises genuine corporate fault. The article looks forward to the cases that are likely to be brought under the "corporate culture" provisions. It suggests that the practical methods of providing evidence of corporate 'attitudes, policies, systems or accepted practices' could very well include the records of meetings, very much in line with the method attempted in the failed Transco prosecution in Scotland. It is submitted that the conceptual foundation for the realist approach is sound and that there are practical ways of bringing the company before the court. However, there are also some conceptual and practical difficulties to be faced. Issues identified include the question of responsibility for sub-cultures and the practical problem of a proliferation of different sorts of evidence and expert opinions that could be put before the courts.]

\section{BACKGROUND}

Corporate responsibility for crimes that require thought, or lack of thought, has been the subject of much debate both in the UK and worldwide. ${ }^{1}$ This article

\footnotetext{
*Professor, School of Law, University of Dundee, Dundee. The author is grateful to the Arts and Humanities Research Council that funded this research under leave award AH/ D500370 / 1.

${ }^{1}$ A frequently cited US work is J Coffee, 'No Soul to Damn: No Body to Kick': An Unscandalized Inquiry into the Problem of Corporate Punishment (1981) 79 Michigan Law Review 386. C Wells, Corporations and Criminal Responsibility $\left(2^{\text {nd }}\right.$ ed, 2001) is a
} 
investigates the current position in the UK, where a Bill is currently (October 2006) ${ }^{2}$ before Parliament, and briefly in Australia, where the law has been reformed at Commonwealth level, but reform has not yet been implemented in individual States. The purpose of the paper is to focus on the sorts of management activity, or inactivity, that may come before the courts either in Australia or the UK. In Australia 'corporate culture', defined as 'an attitude, policy, rule, course of conduct or practice existing within the body corporate generally or in the part of the body corporate in which the relevant activities take place', has been adopted as a key concept. In the UK, the offences of corporate manslaughter (England and Wales) and corporate homicide (Scotland) are likely to be based on the concept of 'senior management failure' which could be evidenced by 'attitudes, policies, systems or accepted practices within the organisation' if they were likely to have encouraged the failure at the root of the crime.

\section{CURRENT POSITION}

In July 2006 the Corporate Manslaughter and Corporate Homicide Bill was introduced in the UK's Westminster Parliament and its second reading has been scheduled for 10 October 2006. The background to this Bill includes two failed prosecutions: the prosecution of P\&O European Ferries (Dover) Ltd for manslaughter under the law of England and Wales following the sinking of the Herald of Free Enterprise in 1987 with the loss of 193 lives; and the prosecution of Transco plc for culpable homicide under the law of Scotland following a gas explosion which destroyed a house with the loss of 4 lives. The corporate manslaughter offence, which is to apply in England and Wales, is largely based on the recommendations of a Law Commission Report of 1996. ${ }^{3}$ The corporate homicide offence, which is to apply in Scotland, has a much shorter history. Following the failure of the Transco prosecution in 2003 the devolved Scottish Executive set up an expert group to address the problem of corporate liability for culpable homicide on the assumption that, as a matter of criminal law, the devolved Scottish Parliament had power to legislate. The expert group reported in November 2005 making a range of recommendations for Scottish legislation. The expert group recognised that it would, in principle, be desirable for the

more comprehensive treatment. B Clark and H Langsford, 'A Re-birth of Corporate Killing? Lessons from America in a New Law for Scotland' (2005) 16 International Company and Commercial Law Review 28 is a recent view on the issue as it relates to Scotland.

${ }^{2}$ Contents of the Bill is stated as at 31 October 2006 as amended in Standing Committee

B (Commons)

${ }^{3}$ Law Commission, Legislating the Criminal Code: Involuntary Manslaughter Report No 237 (1996) 
approaches of the UK jurisdictions to be aligned although the existing law on manslaughter and culpable homicide is not aligned. However the majority felt that alignment should be 'secondary to getting the law right for Scotland. ${ }^{4}$ Also, the expert group felt strongly that the draft Bill for England and Wales was not an appropriate model for Scotland. ${ }^{5}$ Despite this, a parallel offence of corporate homicide was added to the legislation presented to the Westminster Parliament in July 2006. The Scottish Executive is continuing to maintain its devolved power to legislate in this area, but the Bill has gone before the Westminster Parliament without a Sewell motion to return devolved power from the Scottish Parliament to Westminster. A House of Commons Research Paper published on 6 October $2006^{6}$ states:

Campaigners in Scotland have also been critical of the Government's decision to extend the Bill to Scotland, where separate legislation had been proposed. The Government has taken this decision on the basis that the Bill is concerned with health and safety and with business associations, both of which are reserved matters under the Scotland Act $1998 .^{7}$

It appears, therefore, that the UK will consider corporate killing to be a health and safety matter solely due to the constitutional interaction between the UK jurisdictions, and not as a matter of principle. This is an extremely unfortunate outcome as much of the campaigning for the legislation has been because health and safety law was seen as an inappropriate way of dealing with the sorts of incidents to be covered by the new law.

For both jurisdictions, law reform is designed to overcome the problems inherent in the identification doctrine. Under this doctrine, before a company can be convicted of manslaughter an individual who can be identified as the embodiment of the company itself' must be shown them self to have been guilty of the offence. Where there is insufficient evidence to convict the individual, the prosecution of the company must fail. ${ }^{8}$ The doctrine identifies the company with a single human being and the company's thoughts must occur within that single human being. This is despite the fact that the company is explicitly recognised in law as being a legal, but not a natural, person and as being a person separate from

\footnotetext{
${ }^{4}$ Scottish Executive, Corporate Homicide Expert Group Report, Edinburgh, November, 2005, [3.1]

${ }^{5}$ Ibid [3.4].

${ }^{6}$ The Corporate Manslaughter and Corporate Homicide Bill [Bill 220 2005-06] Research Report 06/46.

${ }^{7}$ Ibid Summary of main findings.

${ }^{8}$ Home Office, Reforming the Law on Involuntary Manslaughter: The Government's

Proposals (2000) [3.13].
} 
its directors or shareholders. Law reform measures that recognise the special and different personhood of the company are therefore to be welcomed. To do this it is necessary to imagine an essentially collective, rather than individual, way of thinking.

Commonwealth jurisdictions have traditionally approached corporate criminal responsibility using a 'nominalist' approach that treats the company as a collection of individuals and locates its criminal culpability derivatively through the culpability of individual actors. ${ }^{9}$

The two widely accepted common law bases of corporate responsibility vicarious liability (whereby the corporation is held liable for the conduct of all its officers, employees or agents acting within the scope of their employment or authority) and the 'identification approach' (under which the actions and mental state of certain individual actors are treated as the company's own) - both proceed from the nominalist conception of the 'company' as a fiction, unable to be conceived as blameworthy in itself. ${ }^{10}$

But critics of the nominalist approach have pointed out how it fails to fit with public perceptions of companies. Wells reported that 'the relatives [of the deceased] were keen to see the company properly punished but not the particular individuals whose misfortune it was to be operating the ferry that ... night. ${ }^{, 11}$ It also fails to capture the fact that organisations such as companies function as real entities that are not reducible to propositions about the individuals that compose them. The argument of the 'realists' is that a company is best thought of as something beyond the individuals involved in it. Holistic theories have therefore been developed that locate genuine corporate fault in procedures, systems and culture of the company. It is these theories that have been given legislative force in Australia and are the basis of the Bill before the UK Parliament.

In the Transco prosecution a preliminary diet was held in the High Court, Edinburgh, before Lord Carloway to consider a minute from Transco challenging the competency and relevancy of the charge of culpable homicide. Lord Carloway's finding provides a very useful way of locating the company's guilty thoughts. The relevant, rather long paragraph states:

\footnotetext{
${ }^{9}$ Meaghan Wilkinson, 'Corporate Criminal Liability - The Move Towards Recognising Genuine Corporate Fault' (2003) 9 Canterbury Law Review 142, 142.

${ }^{10}$ Ibid.

${ }^{11}$ C Wells, 'Manslaughter and Corporate Crime’ (1989) 138 New Law Journal 931, 931 cited ibid 162.
} 
In order to bring home guilt, the respondent [prosecution] will have to prove that these committees and posts, or one or more of them, or the board of directors acted in a grossly negligent or reckless manner. ... If, on a given occasion, the committee or post holder knew something or did something then that knowledge, act or omission becomes the knowledge, act or omission of the minuters [Transco] as the company, since all are the knowledge, act or omission of the directing mind and will of the corporation. The acts of a board of directors at one time are the acts of the relevant company just as later or earlier acts are those of the same company even although the membership or the board is entirely different. This is not 'aggregation' or a species of vicarious responsibility but simply an inevitable result of the existence of the corporate veil. It may be that in England there is a need to identify a particular person who could, if charged, also have been guilty of manslaughter ... even if that is so, it is not a requirement under the Scots law of culpable homicide. In cases of the type under consideration here, the duty allegedly breached in a grossly negligent or reckless manner may well be owed only by the corporation and not by any individual person within the company structure. In that situation, there is no reason in principle why the corporation should not be guilty of the crime even although no single individual could be. ${ }^{12}$

This excellent piece of reasoning was, however, rejected and overturned by the Court of Session which held that the charge of culpable homicide must be dismissed as irrelevant. The Court of Session ruling had the effect of causing the unsatisfactory identification principle to be established as a problem of equal magnitude for the jurisdictions of Scotland, and England and Wales.

The Explanatory Notes to the Corporate Manslaughter and Corporate Homicide Bill refers to only one 'new offence', possibly because corporate homicide was added rather late in the day, and the basic elements of the two offences in the Bill are the same. The elements are:

- The organisation must owe a duty of care to the victim that is connected with certain things done by the organisation. ...

- The organisation must be in breach of that duty of care as a result of the way in which certain activities of the organisation were managed or organised by its senior managers. This introduces an element of 'senior management failure' into the offence ....

- This management failure must have caused the victim's death. The usual principles of causation in the criminal law will apply to determine this question.

\footnotetext{
12 Transco plc Minuters (appellants) v Her Majesty's Advocate (respondent) 2004 SCCR 1, 22 (Scotland Appeal Court, High Court of Justiciary, March 2003).
} 
- The breach of duty must have been gross. ... The test asks whether the conduct that constitutes the failure falls far below what could reasonably have been expected. ... Clause 9 [now clause 8 of the Bill] sets out a number of factors for the jury to take into account when considering this issue. There is no question of liability where the management of an activity includes reasonable safeguards and a death nonetheless occurs. ${ }^{13}$

The Explanatory Notes go on to say that senior management failure

looks at how in practice managers organised the performance of a particular activity, rather than focusing on questions of individual culpability, and enables management conduct to be considered collectively as well as individually. ${ }^{, 14}$

The most important change in legal thinking is that this will enable management conduct to be considered collectively as well as individually. In Scotland, the expert group feared that the use of term 'senior management' could result in a return to the need to identify senior managers and thereby a return to the identification principle. The explicit recognition of the need to view collective as well as individual conduct, albeit in the Explanatory Notes, should help to prevent this. The new offences are already being described in terms of 'senior management failure'. So long as the emphasis remains on 'management' failure as a failure to manage properly and does not become 'senior management' failure which could drift into meaning the failure of a senior manager, the collective aspect of the offences should be preserved. Also clause 8 of the Bill explicitly permits the jury to

(3) ... (a) consider the extent to which the evidence shows that there were attitudes, policies, systems or accepted practices within the organisation that were likely to have encouraged any such failure as is mentioned in subsection (2), or to have produced tolerance of it; [and]...

(4) This section does not prevent the jury from having regard to any other matters they consider relevant.

This is the place where the Corporate Manslaughter and Corporate Homicide Bill is closest to the framing of corporate criminal responsibility under the Australian Criminal Code Act 1995 (Cth). The Australian statute provides that a company is responsible when a corporate culture existed within the body corporate that directed, encouraged, tolerated or led to non-compliance with the relevant

\footnotetext{
${ }^{13}$ Corporate Manslaughter and Corporate Homicide Bill, Explanatory Notes, 2006, [14]

(Eng. and Scotland) (emphasis added).

${ }^{14}$ Ibid [15] (emphasis added).
} 
provision. 'Corporate culture' is defined as 'an attitude, policy, rule, course of conduct or practice existing within the body corporate generally or in the part of the body corporate in which the relevant activities take place. ${ }^{15}$ The relevant Criminal Code provisions read:

12.3(1) If intention, knowledge or recklessness is a fault element in relation to a physical element of an offence, that fault element must be attributed to a body corporate that expressly, tacitly or impliedly authorised or permitted the commission of the offence.

(2) The means by which such an authorisation or permission may be established include:

(a) proving that the body corporate's board of directors intentionally, knowingly or recklessly carried out the relevant conduct, or expressly, tacitly or impliedly authorised or permitted the commission of the offence; or

(b) proving that a high managerial agent of the body corporate intentionally, knowingly or recklessly engaged in the relevant conduct, or expressly, tacitly or impliedly authorised or permitted the commission of the offence; or

(c) proving that a corporate culture existed within the body corporate that directed, encouraged, tolerated or led to noncompliance with the relevant provision; or

(d) proving that the body corporate failed to create and maintain a corporate culture that required compliance with the relevant provision. ${ }^{16}$

The explanatory memorandum to this provision states that it will allow

the prosecution to lead evidence that the company's written rules tacitly authorised non-compliance or failed to create a culture of compliance. It would catch situations where, despite formal documents appearing to require compliance, the reality was that non-compliance was expected. For example, employees who know that if they do not break the law to meet production schedules (for example, by removing safety guards or equipment), they will be dismissed. The company would be guilty of intentionally breaching safety legislation. Similarly, the corporate culture may tacitly authorise reckless offending (for example, recklessly disregarding the substantial and unjustifiable

\footnotetext{
${ }^{15}$ Criminal Code Act 1995 (Cth) Part 2.4, s12.3(6).

${ }^{16}$ Ibid s 12.3 (1) and (2).
} 
risk of causing serious injury by removing the equipment guards). The company would be guilty of a reckless endangerment offence. ${ }^{17}$

In England and Wales and in Scotland the offences of corporate manslaughter and corporate homicide respectively will also attribute criminal responsibility to companies on the basis of collective management failure which can be evidenced by failures of corporate culture. In Australia corporate criminal responsibility has been codified in Commonwealth legislation, but the codified method of attributing criminal responsibility only applies directly to federal level crimes. In 2004 there was a failed attempt, using a Private Member's Bill, to create a new offence of industrial manslaughter in Commonwealth legislation. The position within individual States and territories varies. So, for instance, in the Australian Capital Territory the enactment of Part 2.5 of the Criminal Code Act 2002 (ACT) brought the Criminal Code Act 1995 (Cth) into ACT law, but because its provisions did not apply to 'pre 2003' offences, it was also necessary to re-enact new manslaughter provisions. ${ }^{18}$ Other Australian States have approached the issue in various ways and with different degrees of success. ${ }^{19}$ No prosecutions have yet been reported that employ Australia's 'corporate culture' provisions to attribute corporate criminal responsibility.

\section{POSSIBLE EVIDENCE}

In order to bring a case to court based on a management failure located in corporate culture the prosecution will need to assemble evidence of corporate culture. In the failed Transco prosecution the evidence the prosecution sought to bring before the court was evidence from records of meetings. This could have been good evidence of how the company thought. Schwartzman states that 'meetings are significant because they are the organisation or community writ

\footnotetext{
${ }^{17}$ Explanatory Memorandum to the Criminal Code Bill 1994 (Cth) para 7.126

${ }^{18}$ However, the same State has also enacted The Crimes (Industrial Manslaughter) Amendment Act 2003. The 'employer offence' included in this Act applies only to the death of an employee, and can be committed by corporate and non-corporate employer organisations. So, there is some confusion as to which provisions will be used in a prosecution.

${ }^{19}$ Parliament of Australia, Workplace Death and Serious Injury: A Snapshot of Legislative Developments in Australia and Overseas Research Brief no.7 2004-2005 http://www.aph.gov.au/library/Pubs/rb/2004-05/05rb07.htm . The story of Victoria’s attempts to legislate in this area has been told by Karen Wheelwright, 'Corporate Liability For Workplace Deaths And Injuries - Reflecting On Victoria’s Laws In The Light Of The Esso Longford Explosion’ (2002) 7 Deakin Law Review 323.
} 
small'. ${ }^{20}$ Weick argues that 'meetings define, represent, and reproduce social entities. ... Because action that occurs in the meetings is organizational action, this must mean that there really is an organization. Momentarily, at least during the meeting, there appears to be an organization, and this appearance is reconstituted whenever meetings are constituted" ${ }^{21}$ and 'meetings embody the organization and give it some substance. ${ }^{22}$ It is possible to be more specific about the sorts of evidence on corporate culture and health and safety compliance that may be available by looking into the latest methods being employed in organisational theory, safety science, risk management and compliance programs. The next three sections describe and analyse the sorts of evidence that might be generated under the headings 'culture and climate', 'culture and risk management' and 'culture and compliance programs'.

\section{A Culture and Climate}

The discipline most often associated with the study of culture is, of course, anthropology. However, the study of attitudes and perceptions is the realm of social psychology. Research on 'organisational culture' is rooted in anthropology whereas research on 'organisational climate' has developed from a social psychological framework. ${ }^{23}$ There are also two very different approaches or views of organisational culture. These have been described as functionalist and interpretive. The functionalist approach sees organisational culture as something that can, and should, be manipulated to serve corporate interests. The interpretive approach sees it as something that emerges; that is not owned by any group within an organisation but is created by all the organisation's members.

A functionalist perspective is 'top down' in that it serves the strategic imperative of members of the controlling group. An interpretive perspective represents a 'bottom up' approach, and allows for the existence of sub-cultures within an organisation. Most organisations display elements of both approaches. ${ }^{24}$

\footnotetext{
${ }^{20} \mathrm{H}$ B Schwartzman, 'The Significance of Meetings in an American Mental Health Centre’ (1987) 14 American Ethnologist 271, 288.

${ }^{21}$ K E Weick, Sensemaking in Organizations (1995) 143.

${ }^{22}$ Ibid 187.

${ }^{23}$ W.H. Glick, 'Conceptualizing and measuring organizational and psychological climate: pitfalls in multilevel research' (1985) 10 Academy of Management Review 601.

${ }^{24}$ A I Glendon and N A 'Stanton, Perspectives on Safety Culture' (2000) 34 Safety

Science 193, 194.
} 
Culture can also be distinguished from climate in their timing. Whilst culture is often characterised as an enduring aspect of the organisation with trait-like properties, climate can be conceived as a 'temporal manifestation'25 of organisational culture exhibiting more state-like properties. ${ }^{26}$

If organisational culture has failed and a fatal accident has resulted, it is likely that the specific issue will narrow down from the organisation as a whole to its safety culture or safety climate. The relationship between these two concepts has been set out by Cooper who views safety culture as

a product of three interrelated aspects:

- Psychological Aspects or 'safety climate' (individual and group attitudes, perceptions and values).

- Behavioural Aspects (safety-related actions and behaviours).

- Situational Aspects (policies, procedures, organisational structures and management systems). ${ }^{27}$

However, there is a longstanding debate as to the nature and supremacy and applicability of culture versus climate in organisational theory. ${ }^{28}$ There is also a relationship between organisational climate and safety climate which has been explained by Neal et al as follows:

Perceptions of the general organizational climate develop as individuals attribute meaning to their organizational context based on the significance of the environment for individual values. Organizational climate, therefore, is thought to exert a strong impact on individual motivation to achieve work outcomes. General organizational climate has also been found to influence knowledge and skills by increasing participation in activities such as training. Safety climate is a

\footnotetext{
${ }^{25} \mathrm{~S}$ J Cox and A J T Cheyne, 'Assessing Safety Culture in Offshore Environments' (2000) 34 Safety Science 111, 114.

${ }^{26}$ It should also be noted that this is the language of anthropology being used in the field of organisational theory. Roy D'Andrade, The Development of Cognitive Anthropology (1995) 247 states: 'The term trait had been strongly discredited in cultural anthropology since Malinowski.' On culture generally, and what comprises it, D'Andade states that amongst anthropologists there is 'a lack of conceptualization about exactly what was being studied': Ibid 251

${ }^{27}$ Health and Safety Executive, A Review of Safety Culture and Safety Climate Literature for the Development of the Safety Culture Inspection Toolkit (2005) Prepared by Human Engineering, Research Report 367 [7.2].

${ }^{28}$ R Flin, K Mearns, P O'Connor and R Bryden, 'Measuring Safety Climate: Identifying the Common Features' (2000) 34 Safety Science 177, 178.
} 
specific form of organizational climate, which describes individual perceptions of the value of safety in the work environment. ${ }^{29}$

These theoretical definitions and debates are reflected in a multitude of attempts to devise methods, or toolkits, to measure or assess the various concepts as they are exhibited in particular organisations. Flin et al have compared and reviewed a set of safety climate scales and conclude that:

The initial reviews demonstrated that measures vary significantly in almost all respects: content, style, statistical analysis, sample size, sample composition (workers, supervisors, managers), industry and country of origin. Factor analysis is typically used for identification of an underlying structure but numbers of items range from 11 to 300 and thus solutions range from two to 19 factors. Drawing direct comparisons between factor labels and (loading) items across these measures remains problematical due not only to the methodological inconsistencies outlined above, but also to cultural and language differences across both countries and industries. ${ }^{30}$

Despite, or perhaps because of, these difficulties several safety 'toolkits' have been developed. For instance, Cox and Cheyne devised a 'safety climate toolkit' for 'offshore environments' using multiple organisational perspectives and data triangulation. ${ }^{31}$ This toolkit uses approaches that are combined to provide an indepth picture of the organisation's safety climate at the time of the assessment.

During this process reliance is not placed on any single form of assessment, e.g. questionnaires, nor is it placed on any single part of the overall system, e.g. only organisational systems and compliance. It builds upon a holistic approach and provides a 'rich-picture' of the overall safety climate. ${ }^{32}$

The UK's Health and Safety Executive commissioned 'A Review of Safety Culture and Safety Climate Literature for the Development of the Safety Culture

\footnotetext{
${ }^{29}$ A Neal, M A Griffin and P M Hart, 'The Impact of Organizational Climate on Safety Climate and Individual Behaviour’ (2000) 34 Safety Science 99, 100.

${ }^{30}$ Flin et al, above n 21, 179.

${ }^{31}$ The seminal work on triangulation is T D Jick, 'Mixing Qualitative Methods and Quantitative Methods: Triangulation in Action’ (1979) 24 Administrative Science Quarterly 602.

32 S J Cox and A J T Cheyne 'Assessing Safety Culture in Offshore Environments' (2000) 34 Safety Science 111, 126. Drawing on ideas in S Cox and R Flin, 'Safety Culture: Philosopher's Stone or Man of Straw?’ (1998) 12 Work and Stress 189.
} 
Inspection Toolkit.' This appears to be a piece of preparatory work in the development of a toolkit for use by HM Railway Inspectorate. ${ }^{33}$ For this exercise

[t]he scope of the work programme is directed towards developing a tool that captures how a company's safety culture is shaped by corporate practices and organisational behaviour, rather than focusing on the perceptions of staff. The Safety Culture Inspection Toolkit will thus focus on behavioural and situational aspects of an organisation's safety culture. ${ }^{34}$

The resulting toolkit will therefore assess two parts of safety culture, omitting safety climate. The report identifies five indicators upon which the toolkit is to be based: leadership, two-way communication, employee involvement, learning culture and attitude towards blame. ${ }^{35}$ A 'vertical slice' methodology was recommended because of the need to

assess operational workforce, supervisory levels as well as management and strategic thinking in order to identify if the right information, norms and values are being communicated down the hierarchy, as well as there being opportunities for the workforce to communicate to management about health and safety issues. ${ }^{36}$

In addition to the multitude of ways in which safety climate has been assessed there is also the potential for an organisation to have not only an overall culture but also sub-cultures at work within it. A study by McDonald et al reveals how this plays out in practice in the field of aviation maintenance. They found that whilst the organisation's management believe that 'the role of technicians is to follow the task and organisational procedures explicitly, though it is often acknowledged that if everyone followed procedures to the letter, production would be hugely delayed', the technicians believe that they have a professional responsibility for the overall safety of the aircraft. ${ }^{37}$ They conclude from this that the organisation has a strong professional sub-culture operating within it. It is not clear whether a safety culture toolkit employing a 'vertical slice' methodology is capable of capturing an organisation's sub-cultures as such even if it can indicate situations where the organisational norms and values are not being 'communicated down the hierarchy.' A functionalist view of organisational culture suggests that culture is something that can be chosen and shaped by

\footnotetext{
${ }^{33}$ Health and Safety Executive, above n 24, [7.2.2].

${ }^{34}$ Ibid.

${ }^{35}$ Ibid [7.2.3].

${ }^{36}$ Ibid [7.2.10].

${ }^{37}$ N McDonald, S Corrigan, C Daly and S Cromie, 'Safety Management Systems and Safety Culture in Aircraft Maintenance Organisations’ (2000) 34 Safety Science 151, 173.
} 
management. An interpretive view of organisational culture suggests that culture is something not under management's control. The idea that senior management can know and influence corporate culture is implicit in the proposition that a company should be held responsible for its culture. There remains the issue of how far a company should be held responsible for its sub-cultures. In the example of the aircraft maintenance industry, the technicians' sub-culture is one of paying greater attention to safety. A sub-culture will only become problematic if it involves paying less attention to safety and a death results. In the Australian context, Baxt has suggested that the requisite criminality could be attributed to a company as a whole 'where one mutinous branch or subdivision was in the practice of engaging in unlawful conduct in defiance of corporate policy. ${ }^{, 38}$ The Explanatory Notes to the UK Bill state that it

attributes liability to the organisation only for failures in the way on organisation's senior managers managed or organised an activity. This is intended to focus the offence on the overall way in which an activity was being managed or organised by an organisation and to exclude more localised or junior management failings as a basis for liability (although these might provide evidence of management failings at more senior levels). ${ }^{39}$

It is submitted that the wording of the UK Bill leaves it open for a prosecutor to argue that a problem sub-culture provides evidence of the requisite senior management failure.

\section{B Culture and risk management}

If companies are to be held responsible for their culture, governing that culture will be a part of good corporate governance. In fact, corporate governance best practice has already approached this issue using slightly different terminology. The 'internal control' provision of the UK's 'Combined Code' states:

The directors should at least annually conduct a review of the effectiveness of the group's system of internal control and should report to shareholders that they have done so. The review should cover all controls, including financial, operational and compliance controls and risk management.

\footnotetext{
${ }^{38} \mathrm{R}$ Baxt, 'Ascribing Civil and Criminal Liability for Company Employees and Directors - Who Carries the Corporate Can?' Paper presented at Penalties: Policy Principles \& Practice \& Government Regulation (Sydney, 9 June 2001), 4 - cited in Australian Law Reform Commission, ALRC 95 Principled Regulation: Civil and Administrative Penalties in Australian Federal Regulation Part B Corporate Responsibity, Chapter 7 available at ,http://www.austlii.edu.au/au/other/alrc/publications/reports/95/07.Corporate_Responsibili ty.html\#heading2>.

${ }^{39}$ Corporate Manslaughter and Corporate Homicide Bill, Explanatory Notes 2006 [15].
} 
Full implementation of this provision was delayed until guidance could be provided to directors. Internal Control: Guidance for Directors on the Combined Code (the Turnbull guidance) was published in April 1999 and applied to all accounting periods ending on or after 23 December 2000.

Internal control is a concept that has been defined and used routinely by company auditors in their work, eg in the UK Statement of Auditing Standard (SAS) $300 .^{40}$ The UK's Code of Best Practice originated in the work of the Cadbury Committee on the financial aspects of corporate governance, published as the Cadbury Code in December 1992. Prior to Cadbury, the quality of the organisation's internal control was important to those involved in drafting and auditing the annual report, but 'internal control' meant 'internal financial control'. The internal control provision explicitly goes beyond the purely or directly financial. According to Power this provision 'generated fundamental problems about what internal controls really are and what one is saying in describing them as effective. ${ }^{, 41}$ Because the non-financial (or the not-directly-financial) aspects of the provision were new and difficult, the initial response was to restrict its reporting impact, for the time being, to its financial aspect. Under the Rutteman guidance (1994), directors were able to restrict their confirmation of their review of effectiveness of the system of internal control to internal financial control. ${ }^{42}$ However, it was recognised that a partial implementation of the Code could only be sustained in the short term. Conceptually, 'internal control' moved beyond 'internal financial control'. For instance, in a survey of large UK companies conducted in 1994/95, $76.9 \%$ of the finance directors who responded thought that internal controls should not be restricted to financial controls but should be considered in their widest sense. ${ }^{43}$

The Turnbull guidance itself emphasises the wide scope of the Code provision. It states: '[I]nternal controls considered by the board should include all types of controls including those of an operational and compliance nature, as well as

\footnotetext{
${ }^{40}$ Auditing Practices Board, Statement of Auditing Standard (SAS) 300 Accounting and internal control systems and audit risk assessments (1995).

${ }^{41}$ M Power, The Audit Society: Rituals of Verification (1997) 55.

${ }^{42}$ Rutteman Working Group, Internal Control and Financial Reporting - Guidance for Directors of Listed Companies Registered in the UK (1994) (known as 'the Rutteman guidance').

${ }^{43}$ R.W. Mills, 'Internal Control Practices within Large UK Companies' in K Keasey and M Wright (eds), Corporate Governance: Responsibilities, Risks and Remuneration (1997).
} 
internal financial controls. ${ }^{44}$ The significant issue for the Turnbull working party was not whether, but how directors were to deal with the whole of the internal control provision of the Code, and in particular the issue of effectiveness. The answer they have provided is a 'risk-based approach'. The Turnbull guidance states:

A company's objectives, its internal organisation and the environment in which it operates are continually evolving and, as a result, the risks it faces are continually changing. A sound system of internal control therefore depends on a thorough and regular evaluation of the nature and extent of the risks to which the company is exposed. Since profits are, in part, the reward for successful risk-taking in business, the purpose of internal control is to help manage and control risk appropriately rather than eliminate it. ${ }^{45}$

The Turnbull guidance also states that: 'Significant risks may, for example, include those related to market, credit, liquidity, technological, legal, health, safety and environmental, reputation, and business probity issues. ${ }^{, 46}$ The specific risks related to corporate killing therefore come under the ambit of the Turnbull guidance. ${ }^{47}$ The risk that the company's operations will kill one of its employees or a member of the public could be classified as a health, safety or environmental risk. The risk that the company will be convicted of corporate killing could be a legal or reputation risk. Poor reputation was one of the significant risks identified in a Deloitte \& Touche survey reported in Implementing Turnbull: a boardroom briefing. ${ }^{48}$

In order to implement the Turnbull guidance, UK listed companies have had to work out what the application of a risk-based approach means, and its limitations. Across companies, the answers may be different: Turnbull states that each board must 'ensure that the system of internal control is effective in managing risks in the manner which it has approved. ${ }^{49}$ The guidance itself is 'based on the adoption by a company's board of a risk-based approach to establishing a sound system of internal control and reviewing its effectiveness. ${ }^{50}$ This involves the identification and prioritising of risks and embedding the risk management

\footnotetext{
44 The Turnbull Working Party, Internal Control: Guidance for Directors on the Combined Code (1999) (known as 'the Turnbull guidance') [28].

${ }^{45}$ Ibid [13].

${ }^{46}$ Ibid Appendix.

${ }^{47}$ Alice Belcher, 'Corporate Killing as a Corporate Governance Issue’ (2002) 10 Corporate Governance: An International Review 47.

${ }^{48}$ M E Jones and G Sutherland, Implementing Turnbull: A Boardroom Briefing (1999) 14.

${ }^{49}$ Turnbull, above n 44 [16] (emphasis added).

${ }^{50}$ Ibid [9].
} 
approach in the culture and processes of the business. The process envisaged by Turnbull is that the board should, in the light of the company's business objectives, set policies on internal control by considering

the nature and extent of the risks facing the company; the extent and categories of risk which it regards as acceptable for the company to bear; the likelihood of the risks concerned materialising; the company's ability to reduce the incidence and impact on the business of risks that do materialise; and the costs of operating particular controls relative to the benefit thereby obtained in managing the related risks. $^{51}$

Management should implement these policies, but all employees are seen as having some responsibility for internal control as part of their accountability for achieving objectives. Boards should ask: 'Does the company communicate to its employees what is expected of them and the scope of their freedom to act? ${ }^{52}$ The process of changing behaviour at all levels of the company is described as 'embedding' the implementation of Turnbull. From this it can be seen that good corporate governance now involves having risk management policies and embedding these policies in behaviour. This maps onto two of the three aspects in Cooper's definition of culture: the situational and behavioural aspects. It also maps onto two of the elements that a jury may consider under clause 8 of the UK's Corporate Manslaughter and Corporate Homicide Bill: policies and accepted practices. In order for a board to achieve compliance with the current version of the Code of Best Practice it will have to agree a risk management policy and be assured, through the papers presented to it and the asking of questions, that the policies are being carried through into behaviour. The relevant papers and board minutes may not, however, use the terminology of 'safety culture' if they are presented as part of compliance with corporate governance best practice.

However, a risk-management approach is not in itself a guarantee that accidents or disaster will be avoided. Risk management has the appearance of being scientific. The very exercise of identifying and assessing or categorising corporate risks may give the whole process a spurious feeling of certainty and scientific validity. It should be remembered that the identification and assessment of risks will be subjective and there is evidence that individuals treat risks differently depending on how they frame situations. The concept of framing was discussed

\footnotetext{
51 Ibid [17].

${ }^{52}$ Ibid Appendix.
} 
by Kahnemen and Tversky ${ }^{53}$ and later by Bazerman ${ }^{54}$ and Thaller. ${ }^{55}$ The risks of sailing with the bow doors open were, according to the Sheen Report, ${ }^{56}$ not obvious to crews of car ferries before the Zeebrugge disaster. The issue appears not to have been framed in terms of putting to sea with a large hole in the hull. The implementation of a risk-based approach at P\&O European Ferries may not have identified the risk of the disaster that actually happened because the safety issue may not have been framed so as to capture that risk. Institutionalised assumptions and norms that have the capacity to simultaneously illuminate some hazards while shifting attention away from others have been described as a 'fundamental paradox' of organizational safety culture., 57 'Avoiding disaster therefore involves an element of thinking both within administratively defined frames of reference (to deal with well-defined hazards that fall within an organization's prior worldview) and simultaneously stepping outside of those frames (to at least consider the possibility of emergent or ill-defined hazards that have not been identified in advance (or which perhaps fall outside of an organization's strict administrative or legal remit). ${ }^{58}$ Putting the Turnbull guidance into practice will not necessarily mean that organisational procedures will 'step outside' the administratively defined frames of reference. It is more likely that formalising risk management activities in the matrix form suggested under Turnbull will reinforce the 'administratively defined frames'.

\section{Culture and compliance programs}

The Australian formula assigning liability to companies on the basis of corporate culture has been on the statute book long enough for discussion by commentators to have worked through some of its implications. Baxt has argued that it is a formula that can be read as giving legislative force to the emphasis placed on the development and implementation of legal compliance programs. ${ }^{59}$ This is based on section 12.3(2)(d) where responsibility is based on 'proving that the body

\footnotetext{
${ }^{53} \mathrm{D}$ Kahnemen and A Tversky, 'Subjective Probability: A Judgement of Representativeness’ (1972) 3 Cognitive Psychology 430.

${ }^{54}$ M H Bazerman 'The Relevance of Kahneman and Tversky's Concept of Framing to Organisation Behaviour' (1984) 10 Journal of Management 333.

${ }^{55}$ R Thaller, 'Toward a Positive Theory of Consumer Choice' (1980) 1 Journal of Economic Behavior and Organization 39.

${ }^{56}$ Department of Transport (UK), MV Herald of Free Enterprise Report No 8974 (the Sheen Report) (1987).

${ }^{57}$ N Pidgeon and M O'Leary, 'Man-made Disasters: Why Technology and Organizations (Sometimes) Fail (2000) 34 Safety Science 15, 22 referring to N F Pidgeon, 'Safety Culture: Key Theoretical Issues’ (1998) 12 Work and Stress 202.

58 Ibid.

${ }^{59}$ R Baxt, above n 38.
} 
corporate failed to create and maintain a corporate culture that required compliance with the relevant provision.' It should be noted, however, that this does not require the organisation to have a 'compliance program' as such. The provisions in the UK Bill are even less specific on 'compliance'. Companies can be held responsible based on evidence that attitudes, policies, systems or accepted practices within the organisation were likely to have to have 'produced tolerance of' the non-compliance at the root of the crime. In general, the term 'compliance program' is used to refer to a scheme initiated by an organisation in an attempt to ensure its compliance with relevant legislation and regulations. It typically includes a range of measures including education and training of all company employees; advice to the company's agents or subcontractors where applicable; documentation of checks that give management assurance of compliance; and encouragement of employee participation, potentially involving methods for easy communication and whistleblowing. In the Australian context, compliance programs have also been used as 'enforceable undertakings' which are a relatively new form of agreed remedy made available to the Australian Competition and Consumer Commission (ACCC) and the Australian Securities and Investments Commission (ASIC) ${ }^{60}$ A remedy of this sort agreed between the regulator and regulated can be very general and can go beyond the particular sections that have been contravened. However, if a case comes before a court, the power to order a compliance program will depend on the particular remedies available for the specific regulatory breach and a general compliance program will usually be beyond the court's power. ${ }^{61}$ In Australian Competition and Consumer Commission v Real Estate Institute of Western Australia Incorporated French J said:

There was within the ACCC submission in this case a thread of reasoning that seemed to suggest broad compliance programs could be ordered because of their general beneficial effects. It may be accepted without reservation that corporate education in trade practices through wide ranging compliance programs and the fostering of a culture of compliance is good. That does not mean it is appropriate for the Court bounteously to impose the full measure of that good upon a contravener. ${ }^{62}$

\footnotetext{
${ }^{60}$ See Christine Parker, 'Restorative Justice in Business Regulation? The Australian Competition and Consumer Commission's Use of Enforceable Undertakings' (2004) 67 Modern Law Review 209.

${ }^{61}$ Australian Competition and Consumer Commission v Z-Tec Computer Pty Ltd (1997) ATPR 44.

${ }^{62}$ Australian Competition and Consumer Commission v Real Estate Institute of Western Australia Inc (1999) ATPR 41-673 at 42,606.
} 
In the context of the UK Corporate Manslaughter and Corporate Homicide Bill the remedies available to a court will include remedial orders, but limited to steps to remedy the breach itself and 'any matter that appears to the court to have resulted from that breach and to have been a cause of the death. ${ }^{63}$ It will be for the prosecution to make an application for such an order.

It is also important to note that the claim that Australia's statute 'gives legislative force to legal compliance programs' is different in nature from the claim made in the previous section on culture and risk management. The onus placed on the board if it wants to comply with the internal control provision of the Code of Best Practice is to have $a$ risk-management policy and to embed that policy in behaviour throughout the company. However, the question of what the company's attitude to risk should be is not specified. In respect of health and safety law the range of possible attitudes to risk is dealt with, after the fact, in the courts. So in the UK under section 2(1) of the Health and Safety at Work Act 1974 employers have a duty to ensure, so far as reasonably practicable, the health, safety and welfare at work of all their employees. This overriding duty has a moral content; it is wrong to harm your workers. But an employing company can choose to put their workers at risk and take the consequences of that risk-taking choice. In $R v$ Howe (Engineers) $L t d,{ }^{64}$ the Court of Appeal held that the level of fines imposed generally for health and safety offences is too low, that fines need to be large enough to bring home the health and safety message 'not only to the company but also to its shareholders.' Also in assessing the appropriate fine:

Particular aggravating features will include (1) a failure to heed warnings and (2) where the defendant has deliberately profited financially from a failure to take necessary health and safety steps, or specifically run a risk to save money. ${ }^{65}$

This set of principles applies in situations where, and after, a breach of duty has been established, but it is clear that it is intended to also feed into the cost benefit analysis that is envisaged as part of the implementation of Turnbull. However, it does not mean that the result of a particular company's analysis of its expected costs and benefits will produce a decision to spend money moving from a position where it is breach of duty to a position of full compliance with the law.

The nature of the linkage between the company's responsibility for the results of its corporate culture and the obligation to institute 'compliance programs' is also far from clear cut. There is a gap between generalised pronouncements of 'best

\footnotetext{
${ }^{63}$ Corporate Manslaughter and Corporate Homicide Bill, clause 10.

${ }^{64}$ [1999] IRLR 434 (Eng. C.A. 1999)

65 Ibid 437.
} 
practice' or 'good practice' and practice that is poor enough to constitute a breach of duty. In this gap is actual practice that, although it falls below the aspirational standard, does not fall far enough to constitute a breach of duty. This gap can occur in any area where 'best practice' has been set out, for instance health and safety or accident prevention, or corporate governance more generally. The UK courts have yet to pronounce explicitly on the interaction of corporate governance best practices and directors' duties. However, such a case has reached the Delaware Supreme Court: In re The Walt Disney Company Derivative Litigation. $^{66}$ The facts were, briefly, that Disney's CEO, Eisner, lured Ovitz, his long-time friend, to Disney as president and his presumed successor. Disney's board compensation committee approved a pay package for Ovitz without understanding all of its details and implications. Almost immediately after his hiring, other Disney senior executives opposed Ovitz and soon Eisner perceived that his friend did not fit into the company's culture. Ovitz was terminated (not for cause) a little over a year after his hiring and paid the contractually agreed, enormous, severance award. The Delaware Supreme Court compared the 'best practice' approach to Ovitz's hiring with the approach that Disney's compensation committee actually took and held that:

Regrettably, the committee's informational and decision-making process used here was not so tidy. That is one reason why the Chancellor found that although the committee's process did not fall below the level required for a proper exercise of due care, it did fall short of what best practices would have counselled.

All aspects of the Chancery Court's decision were approved by the Supreme Court. The Chancellor had also stated that:

the development of aspirational ideals, however worthy as goals for human behaviour, should not work to distort the legal requirements by which human behaviour is actually measured. ${ }^{67}$

\footnotetext{
${ }^{66}$ No. 15452 (US, Supreme Court, Delaware, June 8, 2006).

${ }^{67}$ Another issue raised before the Delaware Supreme Court was whether responsibility for a breach of directors' duties should be established by looking at the conduct of each individual director in turn, or by looking at the conduct of the board collectively. In the end this issue was not addressed as it was not considered a valid ground for the appeal. The UK position is that: 'Directors have, both collectively and individually, a continuing duty to acquire and maintain a sufficient knowledge and understanding of the company's business to enable them properly to discharge their duties as directors.' (Re Barings plc (No. 5) [2000] 1 BCLC 523, 535 (emphasis added). This is another area where the law needs to grapple with the idea of collective rather than individual responsibility.
} 
Corporate responsibility for failing to create and maintain a corporate culture that requires compliance with the relevant provision (Australia), or for producing tolerance of the non-compliance (UK), is likely to encourage companies to institute compliance programs and to give them importance. However, the use of a general compliance program as a remedy in a corporate killing offence will usually be beyond the power of the court.

\section{CONCLUSIONS}

This article has, from the outset, taken a realist rather than nominalist position on corporate criminal responsibility. This is in line with developments in Australian and the UK law that explicitly recognise genuine corporate fault. The article looks forward to the cases that are likely to be brought under the 'corporate culture' provisions. It suggests that the practical methods of providing evidence of corporate 'attitudes, policies, systems or accepted practices' could very well include the records of meetings, very much in line with the method attempted in the failed Transco prosecution in Scotland. It is submitted that the conceptual foundation for the realist approach is sound and that there are practical ways of bringing the company before the court. However, there are also some conceptual and practical difficulties to be faced. One conceptual issue concerns the functionalist approach to corporate culture that is implicit in the statutes and, in particular, the question of responsibility for sub-cultures. A major practical problem may be the many different sorts of evidence that could be put before the courts and the number of expert opinions that might be presented by both prosecution and defence. For the UK there is also a problem with the level at which responsibility kicks in. The test is whether the conduct that constitutes the failure falls far below what could reasonably have been expected. Whilst the recognition of genuine corporate fault is to be welcomed, convictions may remain illusive. An accused company may be able to argue that the conduct was part of a maverick sub-culture, that the company's culture was in fact adequate as assessed in various complicated ways even if it did not match aspirational 'best practice', and finally that even if the conduct was below a reasonable (rather than aspirational) standard, it was not far below what could reasonably have been expected. 